\title{
COMPLEX ECOLOGICAL AND ENGINEERING ASSESSMENT OF AGRICULTURAL ACTIVITIES PROJECTS
}

\author{
Regina Gurina, Nadiya Khairova, Dmitriy Kucher, Lyutsiya Idrisova \\ Peoples' Friendship University of Russia, Russia \\ gurina_rr@pfur.ru,khairova_ni@pfur.ru,kucher_de@pfur.ru
}

\begin{abstract}
This research analyzes basic theoretical principles underlying a comprehensive environmental engineering assessment of agricultural areas based on an application of a common five-level measuring scale. It is recommended to include such a parameter as "state-impact" in the comprehensive assessment of the environmental situation. This indicator shows a position of natural environmental conditions in accordance with an influence on it. All elements of natural conditions of a particular area need an assessment of the environmental situation and environmental regulation. Moreover, the assessment is made on the basis of compliance with declared and performed environmental functions. It is desirable to pay attention to holistic approaches of the assessment of environmental functions. This can be achieved through the use of a single measuring scale for distribution of parameters and indicators for assessing the parameter values that are not beyond the allowed measurement area, properties of environmental components and the allowed degree of influence on them. The system of environmental assessment of agricultural projects in Russia is new, but its importance for social and economic life is great and it is the subject of ongoing research. Environmental constraints of agricultural activities during implementation of various projects allow the territory to be ranked according to the degree of environmental hazard at regional and local levels and determine admissibility of the future technological impacts on natural objects.
\end{abstract}

Key words: environment, environmental assessment, complex, safety, indicator/parameter "state-impact".

\section{Introduction}

Engineering and environmental assessment of human activities in quantitative and qualitative terms and formation of the system for integrated assessment of meteorological environmental conditions affecting development of agricultural projects and vice versa are urgent issues $[1 ; 2] . \mathrm{H}$ owever, today it is not possible to find a quick and correct solution to these issues. First of all, this is due to the fact that the territories to be assessed include many different components, which make it difficult to assess them [3]. In future, this becomes an obstacle to the formation of comprehensive assessment of all environmental conditions at the state level.

So, what does a comprehensive engineering and environmental assessment include in modern interpretation? There is a number of specific approaches to the understanding of the presented term [4;5]:

1. cumulative characteristic of private assessments, as well as the characteristic of planning plan's assessment of isolated areas of the whole territory in terms of combination of environmental and natural factors that have a positive impact on fundamental types of economic activity;

2. assessment of complex natural ecological systems' state, natural landscapes and their constituent elements is based on the following provisions:

- results of observation of features in various environments (determination of ionizing radiation degree, degree of harmful chemical compound saturation, contaminated areas);

- research and review results;

- results of simulation and formation of cases' variety related to technological and natural issues.

3. it is carried out through the establishment of integral estimates' structural links of the following features:

- quality of natural conditions;

- level of population's normal activity;

- value features of territories;

- alignment by the level of environmental factors impact and a number of similar factors [6;7].

All considered approaches have a common one, which includes the term "integral evaluation". It is formed on the basis of private assessments folding of all elements of the ecological state in the certain area: water, atmospheric air, soil, animal and plant world [8]. 
In other words, a set of natural objects of spatially limited format is investigated. This is a complex that includes ecological systems interconnected by characteristics of some geographic location and the number of similar features [9;10]. All elements of natural conditions of a particular area require an assessment of environmental situation and environmental regulation. Moreover, the assessment is made on the basis of compliance with declared and performed environmental functions.

Attention should be paid to holistic approaches of engineering and environmental assessment of various agricultural projects (Fig. 1). This can be achieved through the use of some single measuring scale for distribution of parameters and indicators for assessing the parameter values that are not beyond the allowed measurement area, properties of environmental components and the allowed degree of influence on them.

\begin{tabular}{|c|c|}
\hline $\begin{array}{l}\text { infrastructure } \\
\text { assessment of financial attractiveness } \\
\text { of investments in agricultural } \\
\text { projects in Russia }\end{array}$ & $\begin{array}{l}\text { selection, assessment and } \\
\text { assistance in registration of land } \\
\text { for placement of agricultural } \\
\text { complexes }\end{array}$ \\
\hline $\begin{array}{l}\text { development of technological } \\
\text { projects of farms, plants for the } \\
\text { production of agricultural products }\end{array}$ & $\begin{array}{l}\text { organization of tours to get } \\
\text { acquainted with the best practices } \\
\text { of agricultural production in } \\
\text { Europe and USA }\end{array}$ \\
\hline
\end{tabular}

OU $\begin{aligned} & \text { support in obtaining government } \\ & \text { subsidies for agricultural projects - } \\ & \text { assistance in selection of suppliers and } \\ & \text { acquisition of agro-industrial equipment } \\ & \text { in Russia and abroad }\end{aligned}$

Fig. 1. Types of agricultural projects

\section{Materials and methods}

In this paper we consider engineering and environmental assessment of some particular area for placement of an agricultural complex. To regulate the property and other economic relations and disputes, including those resolved in the court, it is necessary to conduct a set of special laboratory and field studies to establish the soil condition of the studied area, its resource qualities, risk that threatens human health, and risks that reduce the quality of components environment (water, air, biota) [9].

Evaluation is carried out in several stages. At the first stage, meteorological conditions characteristic of a particular area and types of the territory's application are established; transformations are taken into account from the position of concentration and concentration of influence of various natural factors [8;11]. Next is a preliminary study of the situation. Characteristics of the industrial-technical area are taken into account on the basis of the information obtained as a result of the research, surveys and old documents kept in the archive:

- indirect characteristics;

- collecting data from the public;

- government statistics;

- data by industry.

The first stage is carried out in order to identify the list of the observed parameters of a separate locality separately for all elements. Further, in order to establish significance of the state's parameter of natural conditions of a certain locality, the principle of minimum sufficiency is applied. It lies in the fact that if at least one parameter does not meet the environmental standards, then the state is subject to distortion.

The second stage involves the study of the objects location on the studied land plot and areas that are located directly next to it. This is done to determine the main influencing sources, as well as to identify their specific features and duration of activity. Based on implementation of such a study, 
corrections and additions are possible in the list of the observed parameters depending on the information about the sources of influence obtained as a result of the analysis.

The third stage involves selection of places in the study area intended for selection of samples and environmental parameter assessment. The placement of such places is based on their maximum compliance with certain parameters. To identify the places intended for the selection of samples, techniques are used that meet the analysis goals.

Samples that have undergone rigorous screening are examined to identify indicators for all studied components of natural media. Values are obtained in absolute form. However, to put them in a table, you need to translate them into a relative format.

From the calculated parameters for all items the main state indicator stands out. This is a built indicator, which determines the greatest degree of quality loss for a particular item. Subsequent analysis of information for each item is carried out according to the following formula:

$$
P_{s}=P_{d}+\sum_{i=1}^{n}\left(P_{d p}\right) /\left(\sum_{i=1}^{n}\left(P_{d p}\right)+n\right)
$$

where $P_{s}-$ value of the state parameter of the environment element of the analyzed item;

$P_{d}$ - value on a scale of the main element indicator;

$P_{d p}-$ value on a scale of auxiliary element indicator;

$n$ - number of auxiliary indicators.

The value on the point scale of the main and auxiliary indicators is the median line of the evaluation point character, which corresponds to the relative magnitude of the state of natural conditions and their elements specified in the assessment process on a five-point scale:

- relatively zero $-0.5(<1)$;

- low - $1.5(1-2)$;

- average $-2.5(2-3)$;

- high - 3.5 (3-4);

- catastrophic -4.5 ( $>4)$.

Based on the calculations performed for each element development of a simplified map is carried out, which clearly displays the spatial distribution of the state parameter of surrounding environment with an attachment to the accompanying note (Fig. 2).

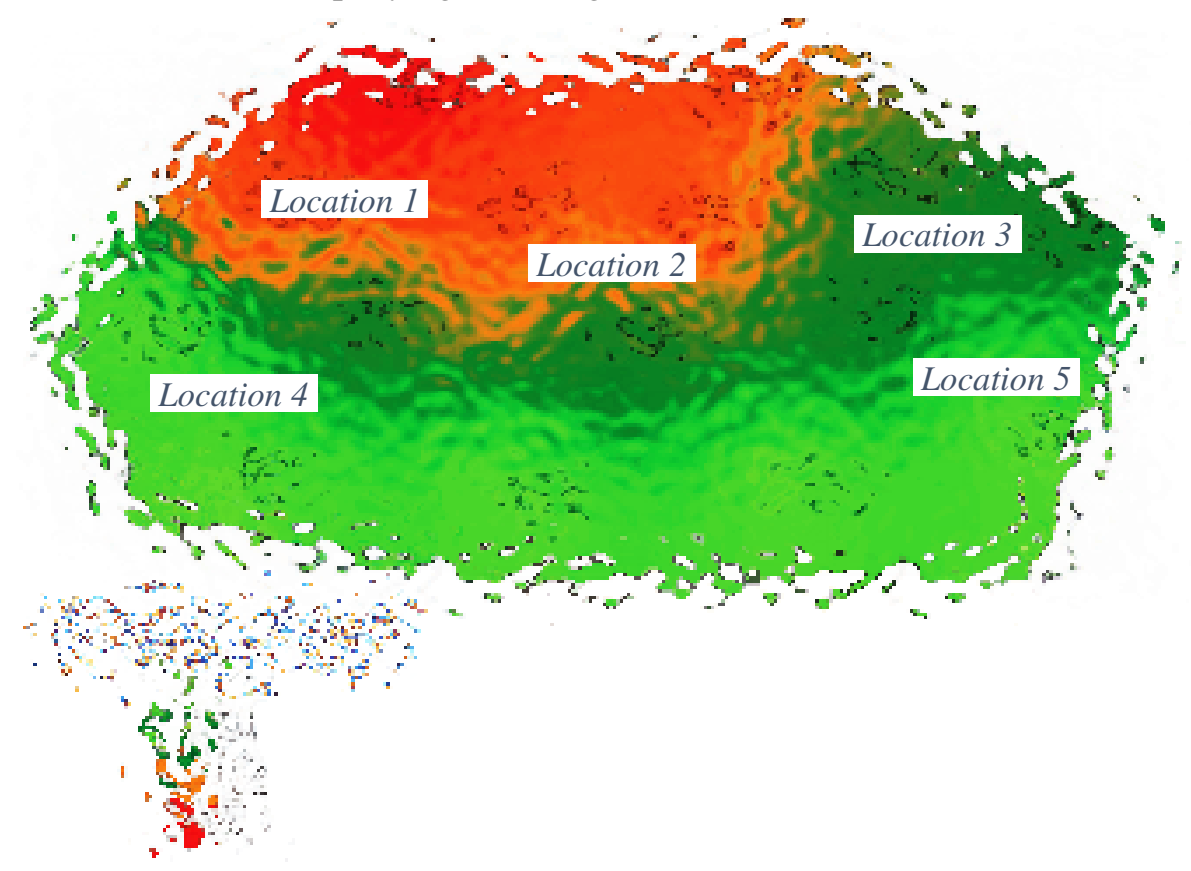

Fig. 2. Approximate simplified map of state of analyzed area 


\section{Results and discussion}

General simplified map of the area state is based on the calculated indicators. It is the final part of the research on implementation of integrated engineering and environmental assessment. Information on the positions of individual elements is included in the final schema, as well as all information and materials obtained during the analysis. On the basis of spatial alignment of a simplified state diagram of individual elements, the state map of natural conditions of the studied area is created with the definition of the required contours. Each contour requires calculation of the value of the state parameter of environment on the proposed formula.

Next, a report is created, which provides full information of environmental assessment of the selected site for agricultural project implementation. The report includes information on the detected distortions or possible improvement of the ecological state in a certain area in dynamics of space-time format, as well as tips on how to take actions to regulate the environmental situation. Systematic assessment of environmental situation of individual areas allows for possibility of conducting a comprehensive study of the environment state as a whole. This allows to take into account all the components of nature that are included in it.

Using of the common five-level measuring scale makes it easier to explain the results obtained during implementation of the study. Inclusion of such an indicator as "state-impact" allows one to obtain information not only on the state of the natural environment components, but also on the impact that it has on it. In other words, the indicator shows the position of natural environmental conditions in accordance with the influence on it. The recommended formula, by means of which determination of the state indicator of surrounding reality is carried out, takes into account dominant and auxiliary factors of influence.

\section{Conclusions}

Recall that to establish the significance of the state parameter of natural conditions of a particular locality, the principle of minimum sufficiency is applied. It lies in the fact that, if at least one parameter does not meet the environmental standards, then the state is subject to distortion. Thus, formation of the final map of the environment state is one of the most convincing methods of imaging the information received. This facilitates use of the information required to regulate various environmental parameters. Adding this assessment to the list of necessary actions in development of agricultural projects (and not only) of our state makes it possible to assess the ecological condition of territories that are of significant size.

\section{Acknowledgements}

The publication was prepared with the support of the RUDN University Program «5-100»

\section{References}

[1] Zhou H., Castro-Lacouture D. Integrated Ecological Assessment of Engineering Projects Based on Emergy Analysis// Energy Procedia, Volume 88, June 2016, pp. 160-167.

[2] Liang L., Lal R., Bradley G. Ridoutt, Guishen Zhao, Wenliang Wu Multi-indicator assessment of a water-saving agricultural engineering project in North Beijing, China// Agricultural Water Management, Volume 200, 1 March 2018, pp. 34-46.

[3] Uzun V., Shagaida N., Lerman Z. Russian agriculture: Growth and institutional challenges// Land Use Policy, Volume 83, April 2019, pp. 475-487.

[4] Куст Г.С., Кутузова Н.Д. Почвенно-экологическая оценка земельных участков: теоретические основы и практические рекомендации к ее проведению (Soil-ecological assessment of land: theoretical foundations and practical recommendations for its implementation) Property relations in the Russian Federation: Имущественные отношения в РФ, 2007, №1(64), c. 79-89 (In Russian)

[5] Рисник Д.В., Беляев С.Д., Булгаков Н.Г., Левич А.П. и др. Подходы к нормированию качества окружающей среды. Законодательные и научные основы существующих систем экологического нормирования (Approaches to the rationing of environmental quality. Legislative and scientific foundations of the existing systems of environmental regulation) 
Successes of modern biology: Успехи современной биологии, 2012. Т. 132. № 6, с. 531-550. (In Russian)

[6] Черненькова Т.В., Левицкая Н.Н., Козлов Д.Н., Тихонова Е.В., Огуреева Г.Н., Пестерова О.А. Оценка состояния и динамики биоразнообразия лесов с использованием наземных и дистанционных методов на примере Московской области (Assessment of the state and dynamics of forest biodiversity using terrestrial and remote methods using the example of Moscow Region) Diversity and dynamics of forest ecosystems in Russia: Разнообразие и динамика лесных экосистем России / Под ред. А.С. Исаева. - М.: КМК, 2012. (In Russian)

[7] Nathan J., Waltham K.,Daffornab A. Ecological engineering in the coastal seascape //Ecological Engineering, Volume 120, September 2018, pp. 554-559

[8] Handbook of Environmental Engineering Assessment, 2012, pp. 1-17

[9] Смагин А.В. Современные проблемы черноземной зоны и возможные пути их решения (Current problems of the chernozem zone and possible ways to solve them) Environmental Bulletin of the North Caucasus: Экологический вестник Сев. Кавказа, 2011. T.7. № 4, с. 8-25 (In Russian)

[10]Шагидуллин Р.Р. Формирование системы эколого-аналитического контроля равнинного водохранилища: автореф. дисс. ... д.х.н. (Formation of the system of ecological-analytical control of a flat reservoir: autoref. dissertation... doc. of Science) Казань, 2012, 38 c. (In Russian)

[11] Agriculture at a crossroads International Assessment of Agricultural Knowledge, Science and Technology for Development [online] [16.02.2019] Available at: http://www.fao.org/fileadmin/templates/est/Investment/Agriculture_at_a_Crossroads_Global_Rep ort_IAASTD.pdf 